\title{
KAJIAN KRITERIA PENENTUAN SKALA PRIORITAS PADA PROYEK PENANGANAN JALAN NASIONAL (Studi Kasus Satuan Kerja Pelaksanaan Jalan Nasional Wilayah II Provinsi Sumatera Utara)
}

\author{
Luther Evi Phanias Girsang ${ }^{1}$ \\ ${ }^{1}$ Mahasiswa Magister Sistem Teknik dan Transportasi, Universitas Gadjah Mada. Griya Ngabeanku, Jl \\ Kaliurang Km 7.5 No.34 Sleman, DIY. Telp : 081210700074 \\ Email: ${ }^{1}$ luther.e.girsang@gmail.com
}

\begin{abstract}
Road infrastructure is one of the most important supports needed for the economy development in industrial areas of North Sumatra. North Sumatra's road infrastructure is often underfunded which has made it difficult to determine the priority order of road infrastructure management resulting in many inequities such as overcrowded roads and increasing numbers of roads in poor condition.

In this study a set of complex structure involving various sectors/indicators will be measured and analyzed using multi criteria research method in the form of Analytical Hierarchy Process (AHP) method. This study includes literature studies from various related sources, discussions, and distributes questionnaires to expert respondents who have competence in the field of transportation, planning, and execution of road infrastructure. The result showed that the order of priority in road infrastructure management from 5 (five) indicators studied is as follows: 1) accessibility function (39.5\%), 2) mobility function (26.1\%), 3) road flow function (15.5\%), 4) road function (13\%), 5) maintenance cost function (6\%).

Subsequent to this, the order of priority in road infrastructure management using Integrated Road Management System (IRMS) method was also investigated resulting in different set of priority order. Based on the comparison of the two methods, the AHP method is recommended to be used because some aspects and criteria can be combined so that the priority order can best describe the needs of the public.
\end{abstract}

Keywords: priority, road infrastructure management, Analytical Hierarchy Process (AHP)

\section{ABSTRAK}

Sektor jalan merupakan salah satu penunjang yang sangat penting bagi perekonomian dalam perkembangan suatu wilayah yang terdapat pada sentra produksi di Provinsi Sumatera Utara. Keterbatasan dana mengakibatkan sulitnya menentukan prioritas penanganan jalan, sehingga banyak ditemukan ketimpangan seperti banyaknya jalan yang belum mendapat penanganan.

Permasalahan pada penelitian ini yang bersifat komplek dengan melibatkan berbagai sektor menjadi alasan mendasar dalam pemilihan metode penelitian multikriteria berupa metode Analytical Hierarchy Process (AHP). Penelitian ini diawali dengan studi literatur dari berbagai sumber terkait, diskusi, dan membagikan kuesioner kepada responden ahli yang memiliki kompetensi di bidang transportasi, perencanaan, dan pelaksanaan. Data hasil kuesioner menunjukkan bahwa dari 5 (lima) kriteria yang diambil dalam penelitian ini yaitu : fungsi aksesibilitas (39.5\%) menduduki peringkat pertama, disusul fungsi mobilitas (26.1\%), fungsi arus ruas jalan (15.5\%), fungsi ruas jalan (13\%) dan fungsi biaya pemeliharaan (6 \%).

Perolehan urutan prioritas penanganan jalan dengan metode AHP pada penelitian ini berbeda hasilnya dengan menggunakan metode Integrated Road Management System (IRMS). Berdasarkan hasil perbandingan dari kedua metode, metode AHP disarankan untuk digunakan karena beberapa aspek dan kriteria dapat dikombinasikan sehingga urutan prioritas dapat menggambarkan kebutuhan masyarakat dengan baik.

Kata Kunci : prioritas, penanganan jalan, Analytical Hierarchy Process (AHP)

\section{PENDAHULUAN}

\subsection{Latar Belakang}

Sektor jalan merupakan salah satu penunjang yang sangat penting dalam perkembangan suatu wilayah. UndangUndang Nomor 38 Tahun 2004 tentang jalan menyatakan bahwa jalan sebagai bagian sistem transportasi nasional mempunyai peranan penting terutama 
dalam mendukung bidang ekonomi, sosial dan budaya serta lingkungan dan dikembangkan melalui pendekatan pengembangan wilayah agar tercapai keseimbangan dan pemerataan pembangunan antar daerah dalam rangka mewujudkan sasaran pembangunan nasional. Untuk tujuan tersebut, maka upaya peningkatan pelayanan sektor jalan di antaranya adalah penanganan jalan dengan prioritas yang memperhitungkan dari berbagai aspek baik teknis maupun non teknis.

Aktifitas masyarakat seiring dengan jumlah penduduk yang semakin meningkat di suatu wilayah merupakan faktor utama pembangkit kebutuhan perjalanan sehingga pada akhirnya perlu adanya tingkat efisiensi, keamanan, serta kenyamanan dalam perjalanan. Peningkatan jumlah pergerakan yang terjadi juga akan menuntut kualitas maupun kuantitas prasarana yang harus seimbang.

Keterbatasan anggaran yang tersedia menuntut pemerintah untuk lebih bijaksana dalam menentukan program pemeliharaan jalan yang tepat. Oleh karena itu dengan kondisi penyediaan dana terbatas maka diperlukan adanya skala prioritas untuk mengoptimalkan fungsi jaringan jalan yang memadai. Hal ini yang mendasari pemikiran untuk menyusun prioritas penanganan ruas jalan nasional di Provinsi Sumatera Utara.

\subsection{Tujuan}

Berdasarkan berbagai alasan di atas maka penelitian ini dilaksanakan untuk menghasilkan alat bantu dalam mendukung pelaksanaan pembangunan jalan dengan tetap menjaga kaidah-kaidah kelestarian lingkungan dan keberlanjutan pembangunan. Pendekatan analisis dengan menggunakan metode Analytic Hierarchy Process (AHP). Penilaian setiap stakeholders terkait sangatlah diperlukan.

\subsection{Tinjauan Pustaka}

Tujuan penanganan jalan adalah untuk mempertahankan kondisi jalan mantap sesuai dengan tingkat pelayanan dan kemampuannya pada saat jalan tersebut selesai dibangun dan dioperasikan sampai dengan tercapainya umur rencana yang telah ditentukan. Bertitik tolak dari kondisi mantap tersebut, pemeliharaan jalan perlu dilakukan secara terusmenerus/rutin dan berkesinambungan khususnya pada jenis konstruksi jalan yang menggunakan sistem perkerasan lentur (flexible pavement). Pemeliharaan jalan tidak hanya pada perkerasannya saja, namun mencakup pula pemeliharaan bangunan pelengkap jalan dan fasilitas beserta sarana-sarana pendukungnya. Perencanaan juga diperlukan dalam pembangunan transportasi termasuk jalan. Di dalam perencanaan sektor transportasi perlu ada pendekatan umum dalam proses perencanaan, dimana semua faktor yang terkait dianalisis sesuai dengan permasalahan yang ada.

\section{METODA PENELITIAN}

\subsection{Analytical Hierarchy Process}

Menurut Saaty, 1993, proses pengambilan keputusan pada dasarnya adalah memilih suatu alternatif. Peralatan utama AHP adalah sebuah hirarki fungsional dengan input utamanya persepsi manusia. Dengan hirarki, suatu masalah kompleks dan tidak terstruktur dipecahkan ke dalam kelompok-kelompoknya dan kemudian kelompok-kelompok tersebut diatur menjadi suatu bentuk hirarki. Langkahlangkah dalam metode AHP meliputi:

1. Mendefinisikan masalah dan menentukan solusi yang diinginkan.

2. Membuat struktur hirarki yang diawali dengan tujuan umum, dilanjutkan dengan subtujuan-subtujuan, kriteria dan kemungkinan alternatif-alternatif pada tingkatan kriteria yang paling bawah.

3. Membuat matriks perbandingan berpasangan yang menggambarkan kontribusi relatif atau pengaruh setiap 
elemen terhadap masing-masing tujuan atau kriteria yang setingkat di atasnya. Perbandingan dilakukan berdasarkan judgment dari pengambil keputusan dengan menilai tingkat kepentingan suatu elemen dibandingkan terhadap elemen yang lainnya.

4. Melakukan perbandingan berpasangan sehingga diperoleh judgment seluruhnya $n[(n-1) / 2]$ buah, dengan $n$ adalah banyaknya elemen yang dibandingkan.

5. Menghitung nilai eigen vector dan menguji konsistensinya. Jika tidak konsisten maka pengambilan data diulangi.

6. Mengulangi langkah 3, 4, dan 5 untuk seluruh tingkat hirarki.

7. Menghitung eigen vector dari setiap matriks perbandingan berpasangan. Nilai eigen vector merupakan bobot setiap elemen. Langkah ini untuk mensintesis judgment dalam penentuan prioritas elemen-elemen pada tingkat hirarki terendah sampai pencapaian tujuan.

8. Memeriksa konsistensi hirarki. Jika nilainya lebih dari 10 persen maka penilaian data judgment harus diperbaiki.

\subsection{Proses Penelitian}

Proses tahapan penelitian untuk studi ini secara umum diperlihatkan melalui bagan alir (Gambar 1) dimana prosedurnya sesuai dengan prinsip dasar AHP yaitu sebagai berikut:

1. Perumusan Masalah

Merumuskan permasalahan yang dihadapi pemerintah pusat yaitu dengan adanya ketidakseimbangan antara kebutuhan pendanaan jalan dengan kemampuan dana APBN, sehingga pemerintah pusat mengalami kesulitan untuk memenuhi SPM jalan.

2. Melakukan Tinjauan Pustaka

Kajian pustaka dilakukan untuk mencari dan mendapatkan teori dan konsep-konsep yang dianggap relevan dan peraturan-peraturan yang menjadi dasar untuk melakukan analisa.

3. Mengumpulkan Data

Pengambilan data dilakukan dengan bantuan kuesioner. Pengambilan data juga dilakukan secara diskusi mendalam kepada responden untuk mengetahui tanggapan lebih mendalam terhadap pendapatnya. Sebelum melakukan penilaian/pembobotan dari responden, dilakukan berdiskusi terlebih dahulu kepada responden terhadap variabel kriteria yang telah diperoleh untuk mendapatkan kesamaan persepsi dan kesepahaman antara peneliti dengan responden. Variabel kriteria yang telah disepakati kemudian menjadi dasar kuesioner baku untuk kemudian dinilai oleh masing-masing responden.

4. Pengolahan dan Analisis Data Penentuan variabel kriteria diperoleh melalui studi literatur yang kemudian dihitung pembobotannya melalui perhitungan dengan metode AHP. Alasan pemilihan metode AHP ini didasarkan pada permasalahan pada penelitian ini yang bersifat komplek dan dari berbagai sektor. Variabel kriteria yang diperoleh pada awal studi literatur disusun hierarkinya secara berkelompok. Hasil penilaian yang diperoleh dari semua responden melalui kuesioner tersebut kemudian dilakukan penilaian rata-rata sehingga menghasilkan nilai dasar yang menjadi input pada matrik dalam proses AHP.

5. Penyusunan Urutan Prioritas Ruas Jalan

Pada tahap ini dilakukan penyusunan urutan prioritas jalan yang akan ditangani pemeliharaannya agar ruas yang telah dinilai dari beberapa kriteria dalam metode AHP tersebut akan diutamakan pengerjaannya.

6. Hasil Data

Hasil data merupakan hasil akhir perhitungan pada metode AHP. Nilai pada masing-masing vektor prioritas 
menunjukan bobot pada variabel kriteria. Nilai bobot tersebut menjadi dasar penyusunan usulan panduan melalui sistematika kriteria kelayakan pembangunan jalan.

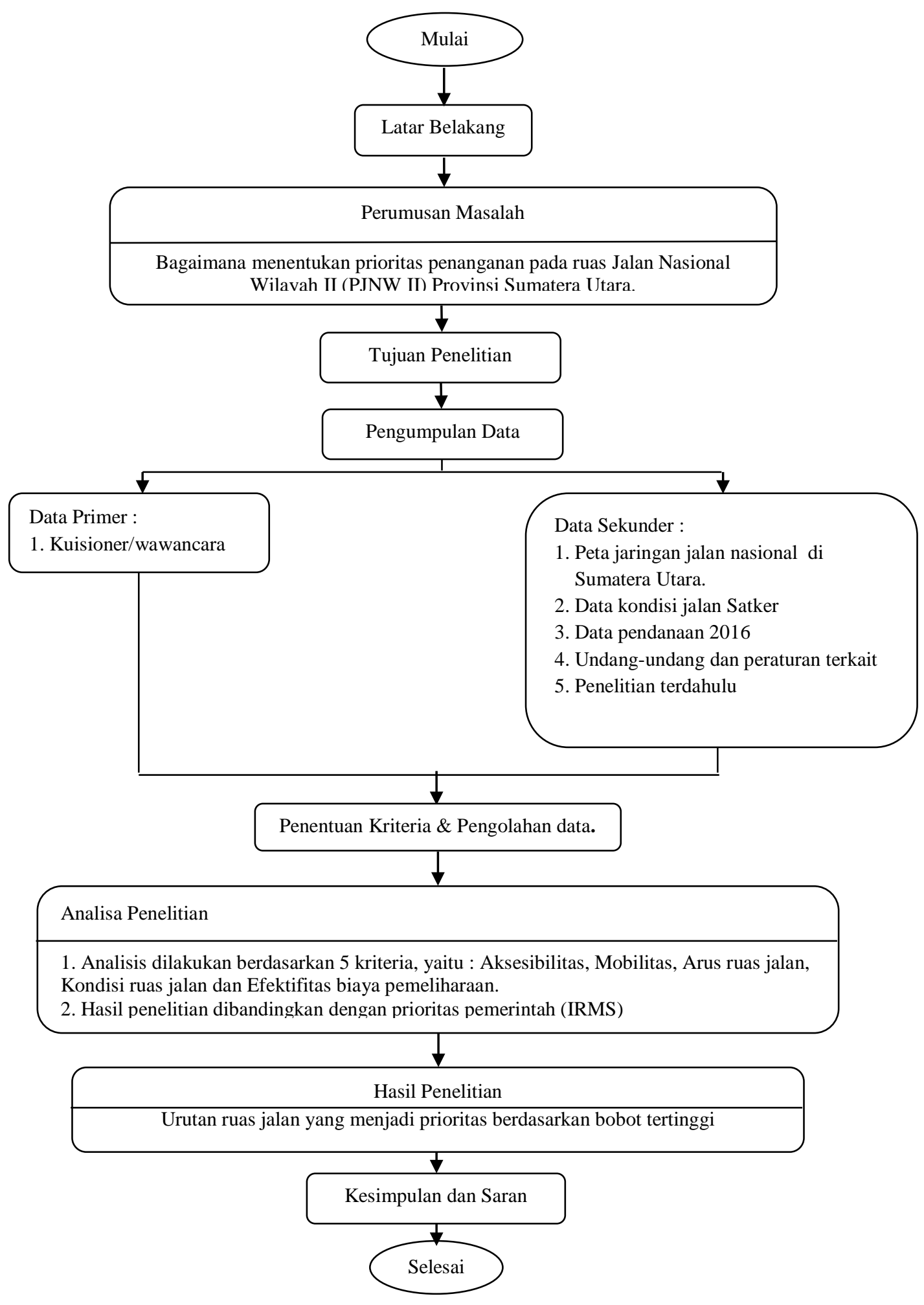

Gambar 1. Bagan Alir Metodologi Penelitian 


\section{HASIL DAN PEMBAHASAN}

\subsection{Bobot Penilaian Kriteria}

Bobot dari masing-masing kriteria, dianalisis dengan metode Analitycal Hierarchy Process (AHP) dengan langkah-langkah sebagai berikut :

1. Perhitungan matrik awal

Diawali dengan menganalisis data pada rekapitulasi jawaban responden terhadap kriteria. Dianalisis dengan perhitungan kebalikan sesuai matrik

Tabel.1 Matrik Awal Kriteria

\begin{tabular}{|l|l|l|l|l|l|}
\hline & A & B & C & D & E \\
\hline A & 1.000 & 2.821 & 2.546 & 2.590 & 4.188 \\
\hline B & 0.354 & 1.000 & 3.909 & 2.145 & 3.335 \\
\hline C & 0.393 & 0.256 & 1.000 & 2.085 & 3.419 \\
\hline D & 0.386 & 0.466 & 0.480 & 1.000 & 3.428 \\
\hline E & 0.239 & 0.300 & 0.292 & 0.292 & 1.000 \\
\hline$\Sigma$ & 2.372 & 4.843 & 8.226 & 8.111 & 15.371 \\
\hline
\end{tabular}
perbandingan berpasangan.

2. Perhitungan eigen vector

Tabel.2 Nilai Eigen Vector Untuk Skala Penentuan Prioritas Kriteria

\begin{tabular}{|c|c|c|c|c|c|c|c|c|}
\hline & $\mathrm{A}$ & $\mathrm{B}$ & $\mathrm{C}$ & $\mathrm{D}$ & $\mathrm{E}$ & Jumlah & Wi & E-Vektor \\
\hline $\mathrm{A}$ & 1.000 & 2.821 & 2.546 & 2.590 & 4.188 & 77.896 & 2.389 & 0.395 \\
\hline $\mathrm{B}$ & 0.354 & 1.000 & 3.909 & 2.145 & 3.335 & 9.910 & 1.582 & 0.261 \\
\hline $\mathrm{C}$ & 0.393 & 0.256 & 1.000 & 2.085 & 3.419 & 0.717 & 0.936 & 0.155 \\
\hline $\mathrm{D}$ & 0.386 & 0.466 & 0.480 & 1.000 & 3.428 & 0.296 & 0.784 & 0.130 \\
\hline $\mathrm{E}$ & 0.239 & 0.300 & 0.292 & 0.292 & 1.000 & 0.006 & 0.361 & 0.060 \\
\hline$\Sigma$ & 2.372 & 4.843 & 8.226 & 8.111 & 15.371 & 88.824 & 6.052 & 1.000 \\
\hline
\end{tabular}

3. Perhitungan nilai eigen maksimum

Nilai eigen maksimum diperoleh dari matrik awal dikalikan dengan E-Vektor masing masing matrik dan kemudian hasil perkalian tersebut dijumlahkan.

\begin{tabular}{|c|c|c|c|c|c|c|c|c|c|}
\hline & A & B & C & D & E & & -Vektor & & \\
\hline A & 1.000 & 2.821 & 2.546 & 2.590 & 4.188 & & 0.395 & & 2.111 \\
\hline B & 0.354 & 1.000 & 3.909 & 2.145 & 3.335 & $\mathrm{X}$ & 0.261 & $=$ & 1.482 \\
\hline C & 0.393 & 0.256 & 1.000 & 2.085 & 3.419 & & 0.155 & & 0.850 \\
\hline D & 0.386 & 0.466 & 0.480 & 1.000 & 3.428 & & 0.130 & & 0.682 \\
\hline E & 0.239 & 0.300 & 0.292 & 0.292 & 1.000 & & 0.060 & & 0.315 \\
\hline
\end{tabular}

Gambar.2 Matrik Nilai Eigen Maksimum Kriteria

4. Kontrol terhadap indek konsistensi Indek konsistensi $(\mathrm{CI})=(\lambda$ maks $-\mathrm{n}) /(\mathrm{n}-1)$, dimana $\mathrm{n}=$ ukuran matrik $=(5.441-5) /(5-1)$

$=0.110345$

$\mathrm{CR}=0.110345 / 1.12$

$=0.098522$; pembobotan : $\underline{\text { konsisten }}$

5. Pembobotan kriteria

Bobot elemen diperoleh dari nilai EVektor yang dinyatakan dalam prosentase seperti diperlihatkan pada Tabel 3 berikut ini :
Tabel.3 Bobot Kriteria Skala Prioritas Penanganan Jalan Nasional

\begin{tabular}{|l|l|}
\hline Kiteria & Bobot \\
\hline Fungsi aksesibilitas & 0.395 \\
\hline Fungsi mobilitas & 0.261 \\
\hline Fungsi arus ruas jalan & 0.155 \\
\hline Fungsi ruas jalan & 0.130 \\
\hline Fungsi biaya pemeliharaan & 0.060 \\
\hline \multicolumn{2}{|c|}{ Jumlah } \\
\hline
\end{tabular}


Kemudian Perhitungan untuk level 3 (subkriteria) dilakukan tahapan yang sama dengan perhitungan kriteria. Besaran bobot kriteria dan subkriteria selanjutnya dapat dirangkum pada Gambar 3 dibawah ini :

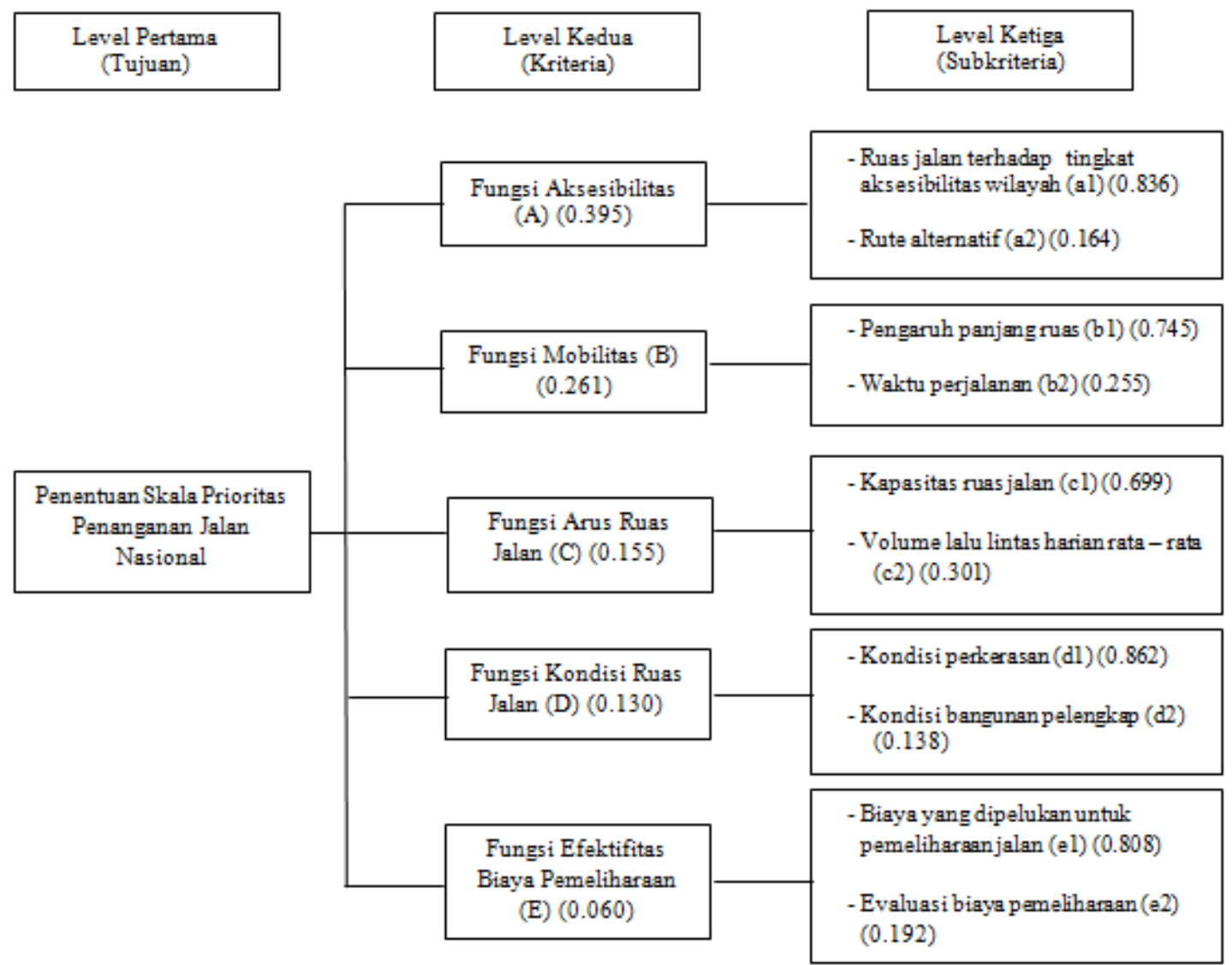

Gambar 3. Bobot Hirarki Skala Prioritas Penanganan Jalan Nasional

\subsection{Skoring Variabel Tingkat Aksesibilitas}

Aksesbilitas adalah suatu ukuran kemudahan bagi pengguna jalan untuk mencapai suatu pusat kegiatan (PK) atau simpul-simpul kegiatan di dalam wilayah yang dilayani jalan. Dalam kriteria aksesibilitas, data yang digunakan adalah panjang jalan dalam satuan kilometer dan luas wilayah berdasarkan tiap kecamatan untuk masing-masing ruas jalan dalam satuan kilometer persegi. Dalam proses skoring, penilaian yang digunakan dalam kriteria aksesibilitas ada pada Tabel 1.

Indeks aksesibilitas jalan yang termasuk kategori memenuhi adalah lebih besar 1.5 $\mathrm{km} / \mathrm{km}^{2}$, artinya wilayah dengan luas 1 $\mathrm{km}^{2}$ terdapat jalan sepanjang $1.5 \mathrm{Km}$ yang melayani wilayah tersebut. Untuk Indeks Aksesibilitas lebih besar dari $1.5 \mathrm{~km} / \mathrm{km}^{2}$ diberikan skor 1 , sementara itu untuk wilayah dimana dalam wilayah dengan luas $1 \mathrm{~km}^{2}$, hanya terdapat jalan maksimal sepanjang $0.5 \mathrm{~km}$ yang melayani wilayah tersebut akan diberikan skor 4. Untuk wilayah yang memiliki panjang jalan yang rendah akan diprioritaskan untuk dilakukan penangan jalan untuk meningkatkan Indeks Aksesibilitas di wilayah tersebut.

Tabel.4 Penilaian Skor Untuk Kriteria Aksesibilitas

\begin{tabular}{lll}
\hline No & $\begin{array}{l}\text { Indeks aksesibilitas/IA } \\
\left(\mathrm{Km} / \mathrm{Km}^{2}\right)\end{array}$ & Skor \\
\hline 1 & IA $>1.5$ & 1 \\
2 & $1 \leq \mathrm{IA} \geq 1.5$ & 2 \\
3 & $0.5<\mathrm{IA}>1$ & 3 \\
4 & $0 \leq \mathrm{IA} \geq 0.5$ & 4 \\
\hline
\end{tabular}


3.3 Skoring Variabel Tingkat Mobilitas

Mobilitas adalah ukuran kualitas pelayanan jalan yang diukur oleh kemudahan per individu masyarakat melakukan perjalanan melalui jalan untuk mencapai tujuannya. Data yang dibutuhkan dalam kriteria mobilitas ini adalah panjang jalan dalam kilometer dan jumlah penduduk yang dilayani untuk masing-masing ruas. Dalam proses skoring, penilaian yang digunakan dalam kriteria mobilitas adalah :

Tabel.5 Penilaian Skor Untuk Kriteria Mobilitas

\begin{tabular}{ccc}
\hline No & $\begin{array}{c}\text { Indeks mobilitas/IM } \\
(\mathrm{KM} / 1000 \text { orang) }\end{array}$ & Skor \\
\hline 1 & $\mathrm{IM}>5$ & 1 \\
2 & $3 \leq \mathrm{IM} \geq 5$ & 2 \\
3 & $1.5 \leq \mathrm{IM} \geq 3$ & 3 \\
4 & $0 \leq \mathrm{IM} \geq 1.5$ & 4 \\
\hline
\end{tabular}

\subsection{Skoring Variabel Tingkat Arus Ruas Jalan}

Derajat kejenuhan (DS) menjadi parameter dalam penilaian terhadap kondisi arus ruas jalan. Derajat kejenuhan adalah perbandingan arus ruas jalan terhadap kapasitas. Ini merupakan indikator suatu ruas jalan dikatakan baik atau buruk, berdasarkan asumsi jika ruas jalan makin dekat dengan kapasitasnya kemudahan bergerak makin terbatas. Skoring variabel kapasitas dari masingmasing ruas jalan dengan rumus yang digunakan dalam Manual Kapasitas Jalan Indonesia (MKJI) yaitu : C = Co x FCw x FCsp x FCsf. Co untuk jalan dua lajur dua arah tak terbagi adalah 2900 smp/jam.
Tabel.6 Penilaian Skor Untuk Kriteria Arus Ruas Jalan

\begin{tabular}{lll}
\hline No & Kapasitas (C) & Skor \\
\hline 1 & $\mathrm{C} \leq 2400$ & 1 \\
2 & $2400 \leq \mathrm{C} \leq 2600$ & 2 \\
3 & $2600 \leq \mathrm{C} \leq 2800$ & 3 \\
4 & $\mathrm{C} \geq 2800$ & 4 \\
\hline
\end{tabular}

\subsection{Skoring Variabel Tingkat Kondisi Ruas Jalan}

Data kekasaran perkerasan (roughness) diperoleh dari survei memakai alat Roughmeter NAASRA dan memberikan nilai International Roughness Index (IRI) yang menjadi parameter untuk melakukan penilaian kondisi perkerasan secara fungsional. Data kondisi permukaan perkerasan diperoleh berdasarkan survei visual setiap 100 meter dengan menggunakan form survei standar Bina Marga. Hasil survei diolah berdasarkan Manual Bina Marga, untuk menghasilkan nilai Surface Distress Index (SDI). Setelah mengetahui nilai rata-rata International Roughness Index (IRI) dan Surface Distress Index (SDI).

Tabel.7 Penilaian Skor Untuk Kriteria Kondisi Ruas Jalan

\begin{tabular}{lll}
\hline No & Kondisi Ruas Jalan & Skor \\
\hline 1 & Baik & 1 \\
2 & Sedang & 2 \\
3 & Rusak Ringan & 3 \\
4 & Rusak Berat & 4
\end{tabular}

\subsection{Skoring Variabel Tingkat Efektifitas Biaya Pemeliharaan}

Skoring variabel efektifitas biaya pemeliharaan dari masing-masing alternatif ruas jalan diperoleh setelah menghitung biaya pemeliharaan masingmasing ruas jalan yang dibutuhkan. Penentuan skoring berdasarkan efektifitas biaya pemeliharaan adalah ruas jalan yang memiliki biaya total yang rendah akan lebih diprioritaskan (skoring 4) daripada biaya total yang tinggi. 
Tabel.8 Penilaian Skor Untuk Kriteria Efektifitas Biaya Pemeliharaan

\begin{tabular}{|l|l|l|l|}
\hline No & Ruas Jalan & $\begin{array}{l}\text { Total } \\
\text { Biaya } \\
\text { (Rp) }\end{array}$ & Skoring \\
\hline 1 & $\begin{array}{l}\text { Rekonstruksi Rampa - Poriaha / } \\
\text { Mungkur (MYC Winrip) }\end{array}$ & 39.315 .000 .000 & 4 \\
\hline 2 & $\begin{array}{l}\text { Pelebaran Jalan Bts. Kota Sibolga - } \\
\text { Bts. Kab. Tapsel (MYC WINRIP) }\end{array}$ & 99.912 .000 .000 & 3 \\
\hline 3 & $\begin{array}{l}\text { Rekonstruksi Jalan Rianiate - Batu } \\
\text { Mundom (MYC APBNP) }\end{array}$ & 122.000 .000 .000 & 2 \\
\hline 4 & $\begin{array}{l}\text { Rekonstruksi Jalan Batu Mundom - } \\
\text { Tabuyung - Natal (MYC APBNP) }\end{array}$ & 131.000 .000 .000 & 1 \\
\hline
\end{tabular}

\subsection{Urutan Prioritas Jalan Pada Tahun Anggaran 2016 Berdasarkan AHP dan IRMS}

Setelah ditentukan besaran bobot pada masing-masing elemen maka untuk menentukan skala prioritas penanganan jalan dengan metode AHP selanjutnya dimasukkan dengan perhitungan model matematis menurut Brojonegoro (1991).
Selanjutnya dilakukan perhitungan besaran Y :

$\mathrm{Y}=$ bobot kriteria $\mathrm{x}$ (bobot alternatif responden $\mathrm{x}$ bobot alternatif sekunder)

$=\mathrm{A} *(\mathrm{a} 1 *$ fungsi aksesibilitas $)+$ $\mathrm{B}^{*}(\mathrm{~b} 1 *$ fungsi mobilitas $)+\mathrm{C}^{*}(\mathrm{c} 1 *$ fungsi arus ruas jalan $)+\mathrm{D}^{*}(\mathrm{~d} 1 *$ fungsi kondisi ruas jalan $)+E^{*}\left(e 1^{*}\right.$ fungsi efektifitas biaya pemeliharaan)

Tabel.9 Urutan Skala Prioritas Penanganan Jalan Dengan Metode AHP

\begin{tabular}{|c|c|c|}
\hline No & Ruas Jalan & $\begin{array}{c}\text { Urutan } \\
\text { Prioritas }\end{array}$ \\
\hline 1 & $\begin{array}{c}\text { Rekonstruksi Rampa - Poriaha / Mungkur (MYC } \\
\text { Winrip) }\end{array}$ & 1 \\
\hline 2 & $\begin{array}{c}\text { Rekonstruksi Jalan Rianiate - Batu Mundom (MYC } \\
\text { APBNP) }\end{array}$ & 2 \\
\hline 3 & $\begin{array}{c}\text { Rekonstruksi Jalan Batu Mundom - Tabuyung - Natal } \\
\text { (MYC APBNP) }\end{array}$ & 3 \\
\hline 4 & $\begin{array}{c}\text { Pelebaran Jalan Bts. Kota Sibolga - Bts. Kab. Tapsel } \\
\text { (MYC WINRIP) }\end{array}$ \\
\hline
\end{tabular}

Tabel.10 Urutan Skala Prioritas Penanganan Jalan Dengan Metode IRMS

\begin{tabular}{|c|c|c|c|c|}
\hline $\begin{array}{c}\text { No Urut } \\
\text { Prioritas }\end{array}$ & Ruas Jalan & $\begin{array}{c}\text { Efektif } \\
(\mathrm{Km})\end{array}$ & $\begin{array}{c}\text { Fungsional } \\
(\mathrm{Km})\end{array}$ & Biaya (10 \\
\hline 1 & $\begin{array}{c}\text { Rekonstruksi Rampa - Poriaha / } \\
\text { Mungkur (MYC Winrip) }\end{array}$ & 9.7 & - & 11.770 .000 \\
\hline 2 & $\begin{array}{c}\text { Pelebaran Jalan Bts. Kota } \\
\text { Sibolga - Bts. Kab. Tapsel } \\
\text { (MYC WINRIP) }\end{array}$ & 36 & - & 29.912 .000 \\
\hline 3 & $\begin{array}{c}\text { Rekonstruksi Jalan Batu } \\
\text { Mundom - Tabuyung - Natal } \\
\text { (MYC APBNP) }\end{array}$ & 49.37 & - & 122.000 .000 \\
\hline 4 & $\begin{array}{c}\text { Rekonstruksi Jalan Rianiate - } \\
\text { Batu Mundom (MYC APBNP) }\end{array}$ & 41.41 & - & 131.000 .000 \\
\hline
\end{tabular}

Sumber : Satker PJNW II Provinsi Sumatera Utara 
Tabel.11 Perbandingan Hasil Metode AHP dengan IRMS

\begin{tabular}{|c|c|c|}
\hline \multirow{2}{*}{$\begin{array}{c}\text { No Urut } \\
\text { Prioritas }\end{array}$} & Metode AHP & Mama Ruas \\
\cline { 2 - 3 } & $\begin{array}{c}\text { Rekonstruksi Rampa - Poriaha / } \\
\text { Mungkur (MYC Winrip) }\end{array}$ & $\begin{array}{c}\text { Rekonstruksi Rampa - Poriaha / } \\
\text { Mungkur (MYC Winrip) }\end{array}$ \\
\hline 2 & $\begin{array}{c}\text { Rekonstruksi Jalan Rianiate - } \\
\text { Batu Mundom (MYC APBNP) }\end{array}$ & $\begin{array}{c}\text { Pelebaran Jalan Bts. Kota Sibolga - } \\
\text { Bts. Kab. Tapsel (MYC WINRIP) }\end{array}$ \\
\hline \multirow{2}{*}{3} & $\begin{array}{c}\text { Rekonstruksi Jalan Batu Mundom } \\
\text { - Tabuyung - Natal (MYC } \\
\text { APBNP) }\end{array}$ & $\begin{array}{c}\text { Rekonstruksi Jalan Batu Mundom - } \\
\text { Tabuyung - Natal (MYC APBNP) }\end{array}$ \\
\hline 4 & $\begin{array}{c}\text { Pelebaran Jalan Bts. Kota Sibolga } \\
\text { - Bts. Kab. Tapsel (MYC } \\
\text { WINRIP) }\end{array}$ & $\begin{array}{c}\text { Rekonstruksi Jalan Rianiate - Batu } \\
\text { Mundom (MYC APBNP) }\end{array}$ \\
\hline
\end{tabular}

Berdasarkan hasil analisis dalam penentuan urutan prioritas dan dengan membandingkan hasil urutan prioritas baik yang diperoleh dengan metode AHP maupun dengan metode IRMS, maka terdapat perbedaan urutan prioritas di 2 ruas jalan yaitu : Rekonstruksi Jalan Rianiate - Batu Mundom (MYC APBNP) dengan menggunakan metode AHP berada pada urutan prioritas kedua, sedangkan dengan metode IRMS berada pada urutan prioritas keempat. Begitu pula dengan ruas jalan Pelebaran Jalan Bts. Kota Sibolga - Bts. Kab. Tapsel (MYC WINRIP) dengan menggunakan metode AHP berada pada urutan keempat, sedangkan dengan metode IRMS berada pada urutan kedua. Perbedaan urutan ini terjadi karena metode IRMS menggunakan komponen nomor link dan biaya, sedangkan metode AHP menggunakan faktor aksesibilitas, faktor mobilitas, faktor arus ruas jalan, faktor kondisi ruas jalan dan faktor efektifitas biaya pemeliharaan.

\section{KESIMPULAN}

Setelah dilakukan analisis dalam menyusun prioritas penanganan jalan nasional di Satker Pelaksanaan Jalan Nasional Wilayah II Provinsi Sumatera Utara pada empat ruas jalan yang dijadikan sebagai daerah penelitian maka diperoleh kesimpulan yaitu:
1. Parameter yang digunakan dalam penelitian ini adalah fungsi aksesibilitas, fungsi mobilitas, fungsi arus ruas jalan, fungsi kondisi ruas jalan dan fungsi efektifitas biaya pemeliharaan.

2. Dari analisis metode AHP, menurut responden kriteria yang sangat berpengaruh dalam menentukan prioritas pemeliharaan jalan adalah fungsi aksesibilitas (0.395) lalu diikuti fungsi mobilitas (0.261), fungsi arus ruas jalan (0.155), fungsi kondisi ruas jalan (0.130) dan fungsi efektifitas biaya pemeliharaan (0.060)

3. Hasil kuesioner yang diberikan kepada 18 responden menunjukkan urutan prioritas penanganan jalan nasional berdasarkan metode AHP yaitu : (1) Rekonstruksi Rampa - Poriaha / Mungkur (MYC Winrip), (2) Rekonstruksi Jalan Rianiate - Batu Mundom (MYC APBNP), (3) Rekonstruksi Jalan Batu Mundom Tabuyung - Natal (MYC APBNP), (4) Pelebaran Jalan Bts. Kota Sibolga Bts. Kab. Tapsel (MYC WINRIP)

4. Hasil urutan prioritas penanganan jalan nasional berdasarkan metode IRMS yaitu : (1) Rekonstruksi Rampa - Poriaha / Mungkur (MYC Winrip), (2) Pelebaran Jalan Bts. Kota Sibolga Bts. Kab. Tapsel (MYC WINRIP), (3) Rekonstruksi Jalan Batu Mundom Tabuyung - Natal (MYC APBNP), (4) 
Rekonstruksi Jalan Rianiate - Batu Mundom (MYC APBNP)

5. Berdasarkan hasil analisis dalam penentuan urutan prioritas dan dengan membandingkan hasil urutan prioritas baik yang diperoleh dengan metode AHP maupun dengan metode IRMS, maka terdapat perbedaan urutan prioritas di 2 ruas jalan yaitu : Rekonstruksi Jalan Rianiate - Batu Mundom (MYC APBNP) dengan menggunakan metode AHP berada pada urutan prioritas kedua, sedangkan dengan metode IRMS berada pada urutan prioritas keempat. Begitu pula dengan ruas jalan Pelebaran Jalan Bts. Kota Sibolga Bts. Kab. Tapsel (MYC WINRIP) dengan menggunakan metode AHP berada pada urutan keempat, sedangkan dengan metode IRMS berada pada urutan kedua.

\section{DAFTAR PUSTAKA}

[1] Anggreni I.A.A dan Jennie K. 2009. "Penentuan Prioritas Perbaikan Jalan Untuk Jalan Beraspal Studi Kasus Jalan Jayapura-Sentani Propinsi Papua”, Proceeding PESAT Vol.3 ISSN : 1858-2559, Universitas Gunadarma Depok.

[2] Brodjonegoro, P.S. 1991. "Petunjuk Mengenai Teori dan Aplikasi Model The Analytic Hierarchy Process", Jakarta : Sapta Utama.

[3] Direktorat Jenderal Peraturan Perundang-undangan Republik Indonesia. 2004. "Undang-Undang Republik Indonesia Nomor 38 Tahun 2004 Tentang Jalan”, Jakarta.

[4] Departemen Kimpraswil. 2001. IRMS Training Course.

[5] Fataruba. 2006. "Evaluasi Perbandingan Urutan Prioritas Usulan Proyek Pemeliharaan Jalan Provinsi Eksisting Dengan Metode Pembobotan”, Sulawesi Selatan.
[6] Saaty, T.L. 1986. "Proses Hirarki Analitik Untuk Pengambilan Keputusan Dalam Situasi Yang Kompleks”, Jakarta : PT.Pustaka Binman Pressindo. 